\title{
Endothelin receptors in the human coronary artery, ventricle and atrium
}

\section{A quantitative autoradiographic analysis}

\author{
Willem A. Bax ${ }^{1}$, Anne T. Bruinvels ${ }^{2}$, Robert-Jan van Suylen ${ }^{3}$, Pramod R. Saxena ${ }^{1}$, and Daniel Hoyer ${ }^{2}$ \\ ${ }^{1}$ Department of Pharmacology and ${ }^{3}$ Department of Pathology, Faculty of Medicine and Health Sciences, Erasmus University Rotterdam, \\ Post Box 1738, NL-3000 DR Rotterdam, The Netherlands \\ ${ }^{2}$ Preclinical Research, SANDOZ Pharma Ltd., CH-4002 Basel, Switzerland
}

Received April 14, 1993/Accepted July 10, 1993

Summary. In the present experiments we investigated endothelin (ET) receptors in the human coronary artery, and in ventricular and atrial muscle using quantitative receptor autoradiography. Displacement of $\left[{ }^{125} \mathrm{I}\right] \mathrm{Sf} 6 \mathrm{~b}$ (Sarafotoxin S6b) (30 pM)- and [ ${ }^{125}$ I]ET-1 (30 pM)-labeled binding sites was studied using ET-1, the $\mathrm{ET}_{\mathrm{A}}$ receptor selective ligand BQ-123 (cyclo[D-Asp-L-Pro-D-Val-LLeu-D-Trp-]), and the $\mathrm{ET}_{\mathrm{B}}$ receptor selective ligand $\left[\right.$ Ala $^{1,3,11,15}$ ]ET-1.

Specific binding was more dense in atrium and coronary artery (relative optical density (r.o.d.): $0.14 \pm 0.01$ and $0.16 \pm 0.01$, respectively) than in ventricular muscle (r.o.d.: $0.10 \pm 0.01$ ). In the coronary artery, binding was especially dense in the media. ET-1 displaced $\left[{ }^{125} \mathrm{I}\right] \mathrm{ET}-1$ and $\left.{ }^{125} \mathrm{I}\right] \mathrm{Sf} 6 \mathrm{~b}$ monophasically in atrium, ventricle and coronary artery. [Ala $\left.{ }^{1,3,11,15}\right]$ ET-1 and BQ-123 displaced ${ }^{[25}$ I]ET-1 and $\left[{ }^{125}\right.$ I]Sf6b-labeled sites biphasically in the ventricle and in the atrium. In the human coronary artery, [Ala $\left.{ }^{1,3,11,15}\right]$ ET-1 and BQ-123 displaced $\left[{ }^{125}\right.$ I]ET-1labeled sites monophasically (pIC 50 : ET-1 $(9.72 \pm 0.12)$ $>$ BQ-123 $(6.84 \pm 0.08)>$ Ala $\left.^{1,3,11,15}\right]$ ET-1 $(6.40 \pm 0.12)$. In contrast, [Ala ${ }^{1,3,11,15}$ ]ET-1 and BQ-123 displaced $\left[{ }^{125} \mathrm{I}\right] \mathrm{Sf} 6 \mathrm{~b}$-labeled coronary artery sites biphasically (high affinity $\mathrm{pIC}_{50}$ : BQ-123, 9.03 $\pm 0.25 ; \quad\left[\mathrm{Ala}^{1,3,11,15}\right] \mathrm{ET}-1$, $8.40 \pm 0.14$; low affinity $\mathrm{pIC}_{50}: \mathrm{BQ}-123,7.24 \pm 0.14$; $\left[\right.$ Ala $\left.^{1,3,11,15}\right]$ ET-1, 6.99 \pm 0.09 ).

These data indicate that both $\left[{ }^{125} \mathrm{I}\right] \mathrm{ET}-1$ and $\left[{ }^{125} \mathrm{I}\right]$ Sf6b-labeled $\mathrm{ET}_{\mathrm{A}}$ and $\mathrm{ET}_{\mathrm{B}}$ binding sites in human ventricular and atrial muscle. In the human coronary artery, both radioligands labeled $E T_{\mathrm{A}}$ binding sites, but $\left[{ }^{125} \mathrm{I}\right]$ Sf6b also labeled a non-ET $T_{A}$, non-ET $T_{B}$ binding site with relatively high affinity for both BQ-123 and [Ala ${ }^{1,3,11,15}$ ] ET-1.

Key words: $\mathrm{ET}_{\mathrm{A}}-\mathrm{ET}_{\mathrm{B}}-\mathrm{BQ}-123-\left[\mathrm{Ala}^{1,3,11,15}\right] \mathrm{ET}-1$ - Sarafotoxin S6b - Human heart

Correspondence to W.A. Bax, at the above address

\section{Introduction}

Endothelin (ET) was originally described as a potent vasoconstrictor peptide (Yanigasawa et al. 1988). In addition, Fozard and Wright (1988) described a vasodilatory effect, later found to be mediated, at least partially, by an endothelium-dependent mechanism involving the release of nitric oxide (NO; Fukuda et al. 1990) and/or prostacyclin ( $\mathrm{PGI}_{2} ;$ De Nucci et al. 1990). In the heart, endothelin has been reported to elicit both positive inotropic (Moravec et al. 1989; Kitayoshi et al. 1989; Takanashi and Endoh 1991) and chronotropic (Ishikawa et al. 1989) effects. Furthermore, endothelin induced mitogenesis of vascular smooth muscle cells (Komuro et al. 1988; Ohlstein et al. 1992) and hypertrophy of myocardial cells (Shubeita et al. 1990) indicating that endothelin may play a role in the development of atherosclerosis and cardiac hypertrophy.

Two distinct endothelin receptor subtypes $\left(\mathrm{ET}_{\mathrm{A}}\right.$; Arai et al. 1990 and $E_{B}$; Sakurai et al. 1990) have been cloned. In radioligand binding studies, the $\mathrm{ET}_{\mathrm{A}}$ receptor has somewhat higher affinity for ET-1 in comparison with isopeptides like ET-3 or sarafotoxin S6b. The ET receptor has almost equal affinity for all endothelins and sarafotoxin S6b (Arai et al. 1990; Sakurai et al. 1990; Saeki et al. 1991). The development of selective ligands that distinguish between these receptors has further helped to characterize the receptors present in various tissues such as the lungs (Nakamichi et al. 1992), kidneys (Nambi et al. 1992) and the myocardium (Molenaar et al. 1993). In the diseased human heart obtained from heart transplant recipients, both $\mathrm{ET}_{\mathrm{A}}$ and $\mathrm{ET}_{\mathrm{B}}$ receptors have been described in the atrium and ventricle and in the atrioventricular conducting system, using in situ hybridization and radioligand binding applying $\left[{ }^{125} \mathrm{I}\right] \mathrm{BQ} 3020$, $\left.{ }^{125} \mathrm{I}\right]\left[\mathrm{Ala}^{1,3,11,15}\right] \mathrm{ET}-1$ (both with particularly high affinity for the $\mathrm{ET}_{\mathrm{B}}$ receptor) and the relatively unselective $\left[{ }^{125}\right.$ I]ET- 1 as radioligands (Davenport et al. 1992; Molenaar et al. 1992, 1993).

In the present study we characterized endothelin receptors in the human coronary artery, obtained from 
healthy and diseased hearts. For comparison we also studied endothelin receptors in the human ventricle and human atrium. We used the $\mathrm{ET}_{\mathrm{A}}$ receptor selective ligand BQ-123 (cyclo[D-Asp-L-Pro-D-Val-L-Leu-D-Trp-]; Ihara et al. 1991) and the $E T_{B}$ receptor selective ligand [Ala ${ }^{1,3,11,15}$ ]ET-1 (Nakamichi et al. 1992) and ET-1 to displace binding of the relatively non-selective ligands ${ }^{125}$ I]ET-1 and $\left[{ }^{125}\right.$ I]Sf6b. A part of this study was presented to the British Pharmacological Society (Bax et al. 1993).

\section{Materials and methods}

Preparation of the tissue. A total of 16 human hearts was used in the present investigation. All experiments were approved by the Ethical Committee of the University Hospital Rotterdam 'Dijkzigt', The Netherlands. The hearts were provided by the Rotterdam Heart Valve Bank (Bio Implant Services/Eurotransplant Foundation, Leiden, The Netherlands) after removal of the aortic and pulmonary valves for valve transplantation. Twelve of the hearts were obtained from patients who died of non-cardiac disorders ( 6 cerebrovascular accident, 6 polytrauma; 7 male, 5 female; age $7-55$ years). These hearts were stored at $0-4{ }^{\circ} \mathrm{C}$ in a sterile organ protecting solution immediately following circulatory arrest and arrived in the laboratory within $20 \mathrm{~h}$ after cardiac arrest. Four hearts were obtained from patients undergoing cardiac transplantation ( 2 dilating cardiomyopathy, included in the groups of cardiac atrium and ventricle and 2 end-stage coronary artery disease, included in the coronary artery group; all male; age $41-55$ years). After arrival in the laboratory, the right and left descending coronary artery and samples of free wall of right atrium and left ventricle $\left( \pm 1.5 \mathrm{~cm}^{3}\right)$ were removed and the vessels were cleaned of fat and connective tissue. All samples were embedded in M-1 embedding matrix (Lipshaw, Pittsburgh PA, USA) and frozen in liquid nitrogen. The tissue was kept at $-70^{\circ} \mathrm{C}$ until further use. Serial sections of $10 \mu \mathrm{m}$ were cut on a micro-cryostat and thaw-mounted on gelatin-coated glass slides and kept at $-20^{\circ} \mathrm{C}$ until binding experiments.

Autoradiographic protocol. The slides were thawed and subsequently preincubated for $15 \mathrm{~min}$ in a Tris-BSA buffer, $\mathrm{pH}$ 7.4. (Tris: tris(hydroxymethyl)-aminomethan; BSA: Bovine Serum Albumin; both from Sigma Chemical Co., St. Louis MO, USA). The tissue was then incubated, at room temperature, for $120 \mathrm{~min}$ in $10 \mathrm{ml}$ Tris-BSA buffer containing either $30 \mathrm{pM}\left[{ }^{125} \mathrm{I}\right] \mathrm{ET}-1$ or $30 \mathrm{pM}\left[{ }^{125} \mathrm{I}\right] \mathrm{Sf} 6 \mathrm{~b}$. The incubation buffer also contained chymostatin ( $2 \mathrm{mg} / \mathrm{l}$; Bachem, Bubendorf, Switzerland), leupeptin ( $4 \mathrm{mg} / 1$; Sigma Chemical Co., St. Louis MO, USA), bacitracin (40 mg/l; Sigma, Buchs, Switzerland) and $5 \mathrm{mM} \mathrm{MnCl} 2$. Non-specific binding was assessed in the presence of $0.3 \mu \mathrm{M}$ unlabeled ET-1. Displacement of radioligand binding was studied by adding unlabeled ET-1 (concentration range $1 \mathrm{pM}-0.3 \mu \mathrm{M}$ ), [Ala $\left.{ }^{1,3,11,15}\right] \mathrm{ET}-1$ (concentration range $30 \mathrm{pM}-10 \mu \mathrm{M}$ ) or $\mathrm{BQ}-123$ (concentration range $3 \mathrm{pM}-30 \mu \mathrm{M})$ to the radioligand containing buffer. After incubation, the slides were rinsed twice in ice-cold buffer for $5 \mathrm{~min}$. The slides were then rapidly dried by exposing to a stream of cold air and subsequently apposed to $\left[{ }^{3} \mathrm{H}\right]$ Hyperfilm (Amersham, Buckinghamshire, UK) for $6 \mathrm{~h}$. After exposure the films were developed (Kodak D19, Rochester, New York, USA), fixated and dried. In addition, we performed high resolution autoradiography by placing emulsion-coated (Kodak $\mathrm{NTB}_{3}$, Rochester, New York, USA) glass coverslips to the slides and exposed for $18 \mathrm{~h}$. The coverslip slides were developed (Kodak D19, Rochester, New York, USA) and fixated. Subsequently the tissue was stained with elastic-Van Gieson. Experiments $(n=7-14)$ were performed in two separate sessions.

Analysis of the data. Binding on film was quantified densitometrically using a computerized image analysis system (MCID Imaging Research, St. Catherines, Ontario, Canada). Displacement curves were analyzed for individual segments, generating competition curves for a one or two site-model, depending on the best fit (based on the $\chi^{2}$ values, Grafit, Erithacus Software Ltd., Staines, UK). The slope factor of the displacement curves by $\left[\mathrm{Ala}^{1,3,11,15}\right] \mathrm{ET}-1$ and $\mathrm{BQ}-123$ in the coronary artery were calculated according to De Lean et al. (1978), by fitting the curve in a one-receptor model.

Compounds. $\left[{ }^{125} \mathrm{I}\right] \mathrm{ET}-1$ and $\left[{ }^{125} \mathrm{I}\right] \mathrm{Sf} 6 \mathrm{~b}$ (both with specific activity of $2200 \mathrm{Ci} / \mathrm{mmol}$ ) were purchased from ANAWA (Zürich, Switzerland). ET-1, [Ala $\left.{ }^{1,3,11,15}\right]$ ET-1 and BQ-123 were purchased from Neosystem S.A. (Strasbourg, France).

\section{Results}

Specific binding of $\left[{ }^{125} \mathrm{I}\right] \mathrm{Sf} 6 \mathrm{~b}$ and $\left[{ }^{125} \mathrm{I}\right] \mathrm{ET}-1$ in ventricular and atrial muscle was homogeneously distributed over the tissue and specific binding was more dense in the atrium and the coronary artery (relative optical density (r.o.d.): $0.14 \pm 0.01$ and $0.16 \pm 0.01$ respectively) than in the ventricle (r.o.d.: $0.10 \pm 0.01$; Fig. 1). In the coronary artery, binding on film consisted exclusively of binding to the media, but coverslip high resolution autoradiography revealed also a signal in a thin adventitial layer and between media and the intimal hyperplasia. Labeling in the latter two regions of the vessel consisted mainly of non-specific binding, and did not show on $\left[{ }^{3} \mathrm{H}\right]$ Hyperfilm (Fig. 2).

ET-1 displaced $\left[{ }^{125} \mathrm{I}\right] \mathrm{Sf} 6 \mathrm{~b}$ and $\left[{ }^{125} \mathrm{I}\right] \mathrm{ET}-1$ monophasically in the ventricle (Fig. 3 ; $\mathrm{pIC}_{50}$ values of the curves are shown in Table 1). [Ala ${ }^{1,3,11,15}$ ]ET-1 and BQ-123 displaced $\left[{ }^{125} \mathrm{I}\right] \mathrm{ET}-1$ and $\left[{ }^{125} \mathrm{I}\right] \mathrm{Sf} 6 \mathrm{~b}-\mathrm{labeled}$ sites biphasically in the ventricle. Assuming a two receptor model to be present, the proportion of high-affinity sites of BQ-123 (which should equal the proportion of low affinity sites of $\left.\left[\mathrm{Ala}^{1,3,11,15}\right] \mathrm{ET}-1\right)$ as compared to the high affinity sites of $\left[\mathrm{Ala}^{1,3,11,15}\right] \mathrm{ET}-1$ (which should equal the proportion of low affinity sites of BQ-123) was $53 \pm 3 \%$ : $47 \pm 3 \%$ in the ventricle; percentages for separate curves: see Table 1).

Also in the atrium $\left[{ }^{125} \mathrm{I}\right] \mathrm{Sf} 6 \mathrm{~b}$ and $\left[{ }^{125} \mathrm{I}\right] \mathrm{ET}-1$ were displaced monophasically by ET-1, but biphasically by [Ala ${ }^{1,3,11,15}$ ]ET-1 and BQ-123 (Fig. 4; pIC 50 values of the curves are shown in Table 2). In the atrium, the proportion of high affinity sites of BQ-123 as compared to the high affinity sites of $\left[\mathrm{Ala}^{1,3,11,15}\right]$ ET-1 was $68 \pm 3 \%$ : $32 \pm 3 \%$ (percentages for separate curves: see Table 2 ).

Table 1. Human ventricle. $\mathrm{pIC}_{50}\left(-\mathrm{Log} \mathrm{IC}_{50}\right)$ for the monophasic displacement by ET-1, and in case of biphasic displacement the high $\left(\mathrm{pIC}_{50}\right.$ high) and/or low ( $\mathrm{pIC}_{50}$ low) affinity value and proportion (\% high, $\%$ low) of the affinity phases of $\left[\mathrm{Ala}^{1,3,11,15}\right] \mathrm{ET}-1$ and BQ-123

\begin{tabular}{|c|c|c|c|}
\hline & & $\left.{ }^{125}\right] \mathrm{ET}-1$ & {$\left[{ }^{[25} \mathrm{I}\right] \mathrm{Sf} 6 \mathrm{~b}$} \\
\hline ET-1 & $\mathrm{pIC}_{50}{ }^{\mathrm{a}}$ & $10.16 \pm 0.08$ & $9.49 \pm 0.08$ \\
\hline \multirow{4}{*}[\text{Ala}^{1,3,11,15}]{$\mathrm{ET}-1$} & $\mathrm{pIC}_{50}$ high & $9.59 \pm 0.34$ & $9.48 \pm 0.16$ \\
\hline & $\%$ high & $39.7 \pm 5.1$ & $50.6 \pm 5.1$ \\
\hline & $\mathrm{pIC}_{50}$ low & $6.05 \pm 0.20$ & $6.54 \pm 0.12$ \\
\hline & $\%$ low & $60.3 \pm 5.1$ & $49.4 \pm 5.1$ \\
\hline \multirow[t]{2}{*}{$\mathrm{BQ}-123$} & $\mathrm{pIC}_{50}$ high $^{\mathrm{b}}$ & $7.04 \pm 0.24$ & $7.49 \pm 0.10$ \\
\hline & $0 \%$ high $^{b}$ & $50.1 \pm 5.6$ & $49.4 \pm 14.3$ \\
\hline
\end{tabular}

\footnotetext{
${ }^{a}$ Monophasic complete displacement

b Lower affinity phase could not be analyzed because plateau was reached
} 

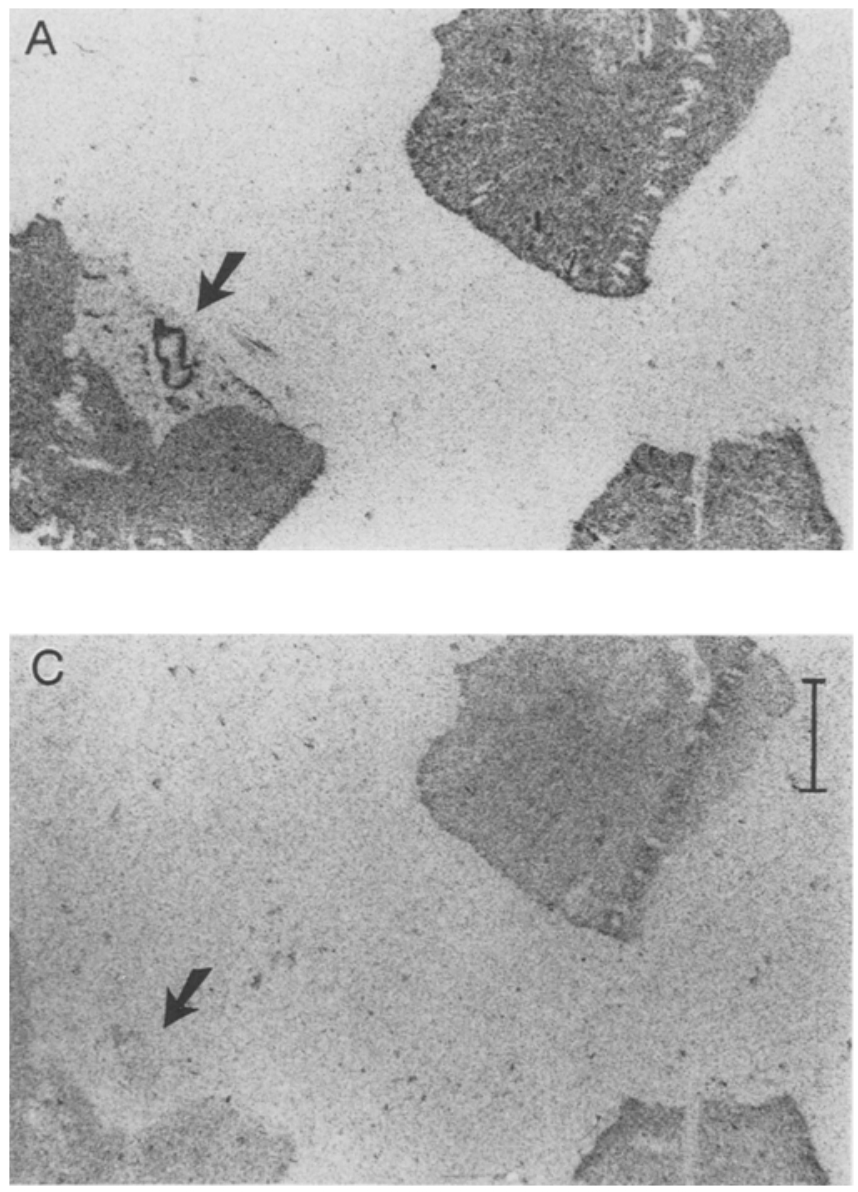

Fig. 1. Autoradiographs of total (A and $B$ ) and non-specific binding (C and $D$ ) of $\left[{ }^{125}\right.$ I]ET-1-labeled ventricular segments (three different patients, $A$ and $C$ ) and one $\left[{ }^{125}\right.$ I]ET-1-labeled atrial segment (B and D). Note differences in receptor density between ventricle on one hand and

In the human coronary artery, ET-1 displaced both $\left[{ }^{125} \mathrm{I}\right] \mathrm{Sf} 6 \mathrm{~b}$ and $\left[{ }^{125} \mathrm{I}\right] \mathrm{ET}-1$ in a monophasic manner. $\left[\right.$ Ala ${ }^{1,3,11,15}$ ]ET-1 and BQ-123 displaced $\left[{ }^{125}\right.$ I]ET-1-labeled sites monophasically in 6 and 7 segments respectively, out of 7 individually analyzed tissue segments. In contrast, $\left[\right.$ Ala $\left.{ }^{1,3,11,15}\right]$ ET-1 and BQ-123 displaced ${ }^{125}$ I]Sf6b-labeled

Table 2. Human atrium. $\mathrm{pIC}_{50}\left(-\log \mathrm{IC}_{50}\right)$ for the monophasic displacement by ET-1, and in case of biphasic displacement the high $\left(\mathrm{pIC}_{50} \mathrm{high}\right)$ and/or low ( $\mathrm{pIC}_{50}$ low) affinity value and proportion (\% high, $\%$ low) of the affinity phases of $\left[\mathrm{Ala}^{1,3,11,15}\right] \mathrm{ET}-1$ and BQ-123

\begin{tabular}{|c|c|c|c|}
\hline & & {$\left[{ }^{125} \mathrm{I}\right] \mathrm{ET}-1$} & {$\left[{ }^{125} \mathrm{I}\right] \mathrm{Sf} 6 \mathrm{~b}$} \\
\hline \multirow{5}{*}{$\begin{array}{l}\text { ET-1 } \\
\left.\text { [Ala }^{1,3,11,15}\right] \text { ET-1 }\end{array}$} & $\mathrm{pIC}_{50}{ }^{\mathrm{a}}$ & $9.61 \pm 0.04$ & $8.95 \pm 0.07$ \\
\hline & $\mathrm{pIC}_{50}$ high & $9.05 \pm 0.33$ & $9.36 \pm 0.09$ \\
\hline & $\%$ high & $27.9 \pm 5.1$ & $24.7 \pm 2.7$ \\
\hline & $\mathrm{pIC}_{50}$ low & $5.79 \pm 0.17$ & $6.91 \pm 0.05$ \\
\hline & $\%$ low & $72.1 \pm 5.1$ & $75.3 \pm 2.7$ \\
\hline \multirow[t]{2}{*}{$B Q-123$} & $\mathrm{pIC}_{50}$ high $^{\mathrm{b}}$ & $6.67 \pm 0.12$ & $7.45 \pm 0.40$ \\
\hline & $\%$ high $^{b}$ & $58.7 \pm 5.5$ & $48.3 \pm 13.2$ \\
\hline
\end{tabular}

\footnotetext{
a Monophasic complete displacement

b Lower affinity phase could not be analyzed because plateau was reached
}
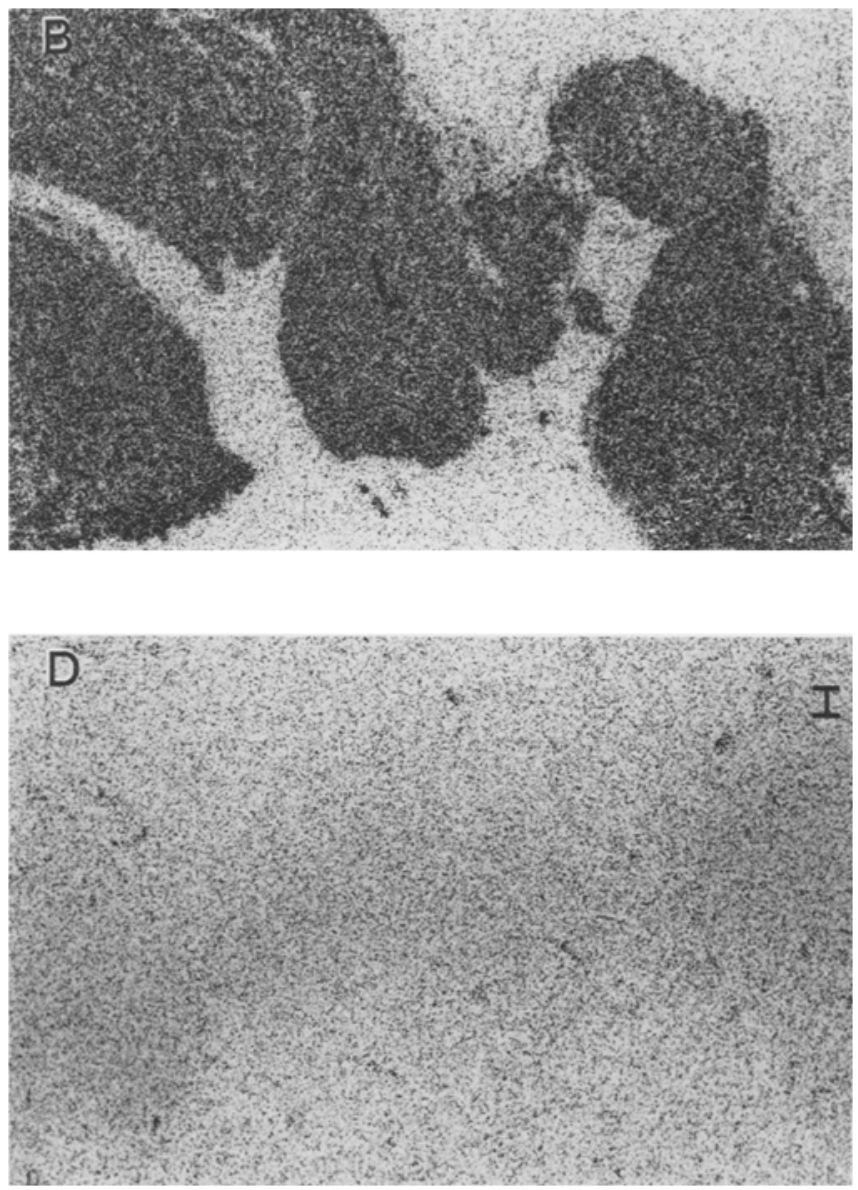

atrium and coronary artery (embedded in fat attached to the left ventricle: A and C, arrow) on the other hand. Scale bars: panel C, $4 \mathrm{~mm}$; panel $\mathrm{D}, 0.5 \mathrm{~mm}$

sites biphasically in 9 segments each, out of 14 individually analyzed coronary artery segments. Also analysis of the mean curves in the coronary artery revealed a monophasic curve as the best fit for the displacement of $\left[{ }^{125} \mathrm{I}\right]$ ET-1 by $\left[\mathrm{Ala}^{1,3,11,15}\right] \mathrm{ET}-1$ and $\mathrm{BQ}-123$, whereas the displacement of $\left[{ }^{125} \mathrm{I}\right] \mathrm{Sf} 6 \mathrm{~b}$ by [Ala $\left.{ }^{1,3,11,15}\right] \mathrm{ET}-1$ and BQ-123 were both best described by a biphasic curve (Fig. 5). In addition, the slope factor (or pseudo Hill number) of the displacement curve of $\left[{ }^{125} \mathrm{I}\right] \mathrm{Sf} 6 \mathrm{~b}$ by $\left[\mathrm{Ala}^{1,3,11,15}\right]$ ET- 1 or $\mathrm{BQ}-123$, when fitted to a monophasic model according to De Lean et al. (1978); was significantly lower $(0.64 \pm 0.09$ and $0.69 \pm 0.11$ respectively) than the slope of the displacement curve by $\left[\mathrm{Ala}^{1,3,11,15}\right] \mathrm{ET}-1$ or BQ-123 of ${ }^{[25}$ I]ET-1 $(0.95 \pm 0.08)$ and $1.27 \pm 0.14$ respectively). The ${ }^{[25}$ I]Sf6b-labeled proportion of receptors with high affinity for both BQ-123 and $\left[\right.$ Ala $\left.{ }^{1,3,11,15}\right]$ ET-1 was $49 \pm 4 \%: 51 \pm 4 \%$ when compared to the proportion of $\left[{ }^{125}\right.$ I]Sf6b-labeled- sites with 'low' affinity for BQ-123 and $\left[\mathrm{Ala}^{1,3,11,15}\right] \mathrm{ET}-1$. We observed no differences in receptor density, affinity values or slope factors between healthy and diseased hearts. Therefore, the data refer to the mean of all ventricle, atrium or coronary artery samples. 

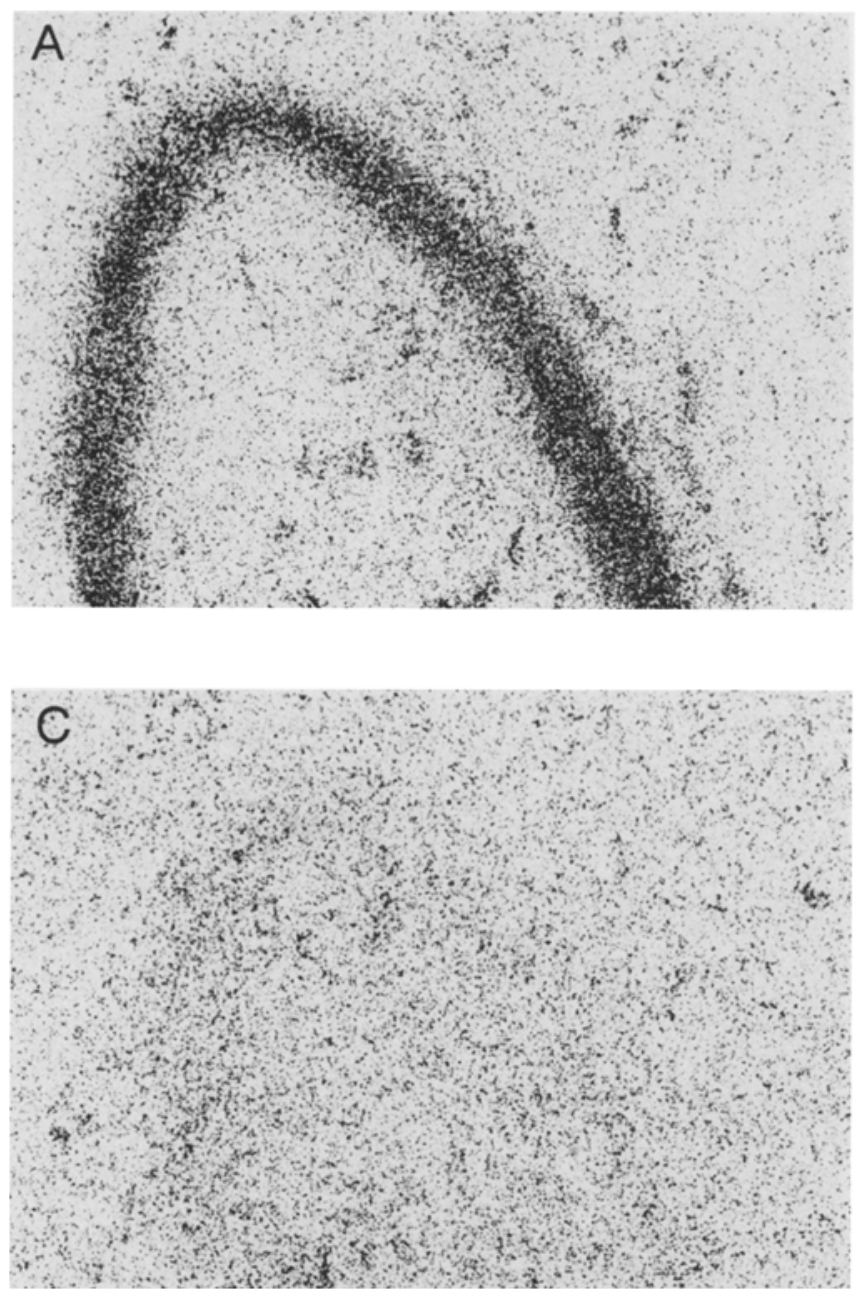

Fig. 2. Left panels: Autoradiography film of total (A) and non-specific (C) binding of one [ ${ }^{125}$ I]ET-1-labeled coronary artery segment, obtained from a patient undergoing a cardiac transplantation for ischaemic coronary artery disease. Right panels: High resolution auto-

\section{Discussion}

Both $\left[{ }^{125} \mathrm{I}\right] \mathrm{ET}-1$ and $\left[{ }^{125} \mathrm{I}\right] \mathrm{Sf} 6 \mathrm{~b}$ were found to label a mixed population of binding sites in human ventricle and atrium. Using $\left.{ }^{125} \mathrm{I}\right] \mathrm{ET}-1$, we found an apparently single receptor population in the human coronary artery with characteristics similar to one of the two receptors in the ventricle and atrium. However, the radioligand $\left.{ }^{125} \mathrm{I}\right] \mathrm{Sf} 6 \mathrm{~b}$ also seemed to label a coronary artery site with binding characteristics different from the atrial and ventricular endothelin receptors. It has to be noted that non-specific binding was defined using unlabeled ET-1. In general, non-specific binding should preferably be determined using a cold ligand, different from the radioligands $\left[{ }^{125} \mathrm{I}\right]$ ET-1 and [ $\left.{ }^{125} \mathrm{I}\right] \mathrm{Sf} 6 \mathrm{~b}$. However, little is known about truly non-selective endothelin receptor ligands. Furthermore, the maximum displacement by [Ala $\left.{ }^{1,3,11,15}\right]$ ET-1 and ET-1 was similar for both $\left[{ }^{125} \mathrm{I}\right] \mathrm{ET}-1$ - and $\left[{ }^{125} \mathrm{I}\right] \mathrm{Sf} 6 \mathrm{~b}$-binding in atrium and in ventricle (Figs. 3, 4). In the coronary artery, all three cold ligands (ET-1, [Ala ${ }^{1,3,11,15}$ ]ET-1, and BQ-123) caused a similar amount of total displacement
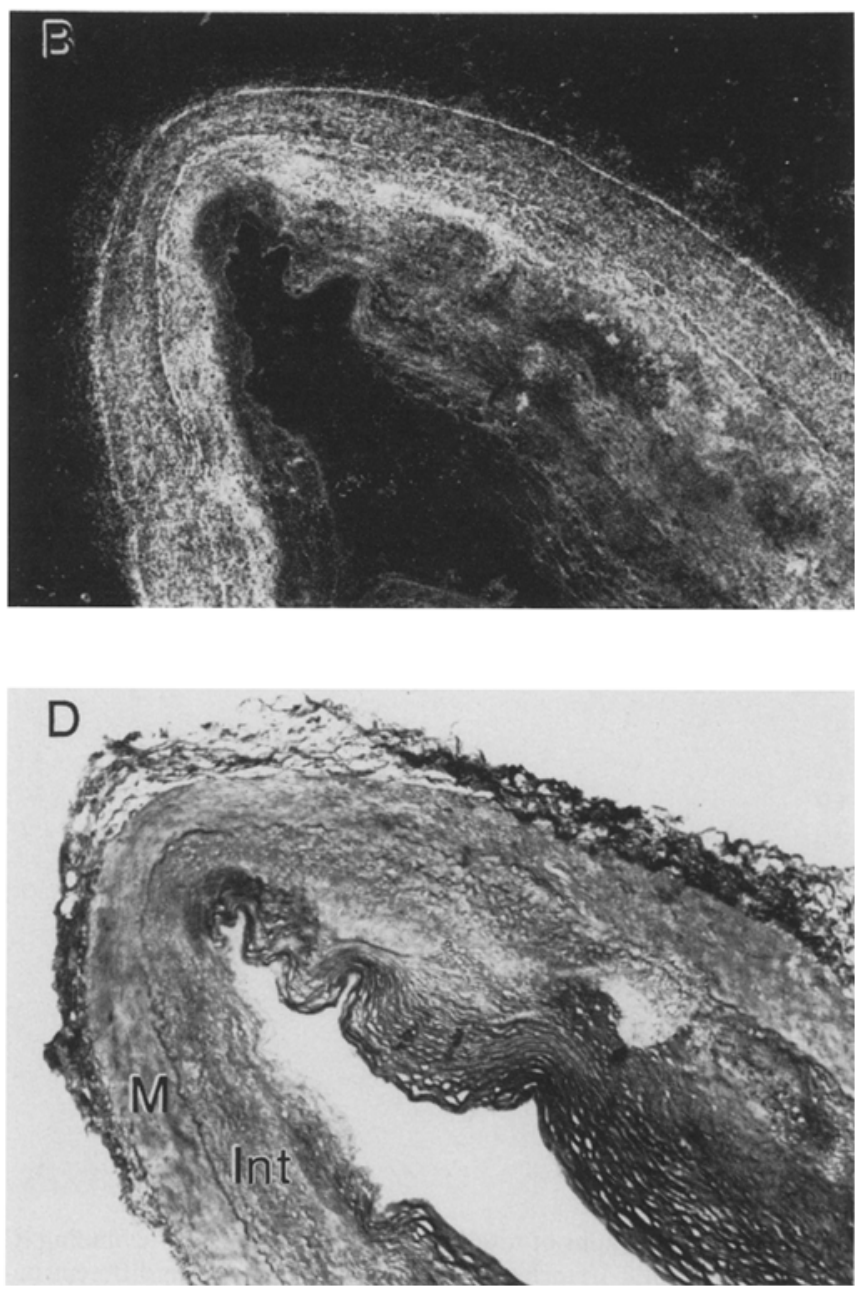

radiography (C) and light microscopy (elastic-Van Gieson staining, $40 \times$, D) of the same coronary artery segment. Int, intima: a combination of intimal hyperplasia and intimal fibrosis; $\mathrm{M}$, media

both for $\left.{ }^{125} \mathrm{I}\right] \mathrm{ET}-1$ and $\left.{ }^{125} \mathrm{I}\right] \mathrm{Sf} 6 \mathrm{~b}$ (Fig. 5). Taken together, this indicates that the use of ET-1 to define non-specific binding is appropriate.

\section{Endothelin receptors in the ventricle and the atrium}

Endothelin has been shown to cause positive inotropic and/or chronotropic effects in the ventricle and atrium of several animal species (Kitayoshi et al. 1989; Ishikawa et al. 1988a, b) and man (Moravec et al. 1989; Davenport et al. 1989; Brodde et al. 1992). In the rabbit isolated papillary muscle, the positive inotropic response appeared to be mediated by the $\mathrm{ET}_{\mathrm{B}}$ receptor (Takanashi and Endoh 1991), but the nature of the receptor involved in endothelin-induced rat myocyte hypertrophy and secretion of natriuretic peptide from rat myocytes (Shubeita et al. 1990) thus far remains unknown. The human ventricle has recently been shown to contain both $\mathrm{ET}_{\mathrm{A}}$ and $\mathrm{ET}_{\mathrm{B}}$ receptors, e.g. by using $\mathrm{BQ}-123$ and $\mathrm{BQ}-3020$ (an $\mathrm{ET}_{\mathrm{B}}$ receptor selective compound) to displace $\left.{ }^{125} \mathrm{I}\right] \mathrm{ET}$-1-labeled sites and also by showing the presence of mRNA strands 

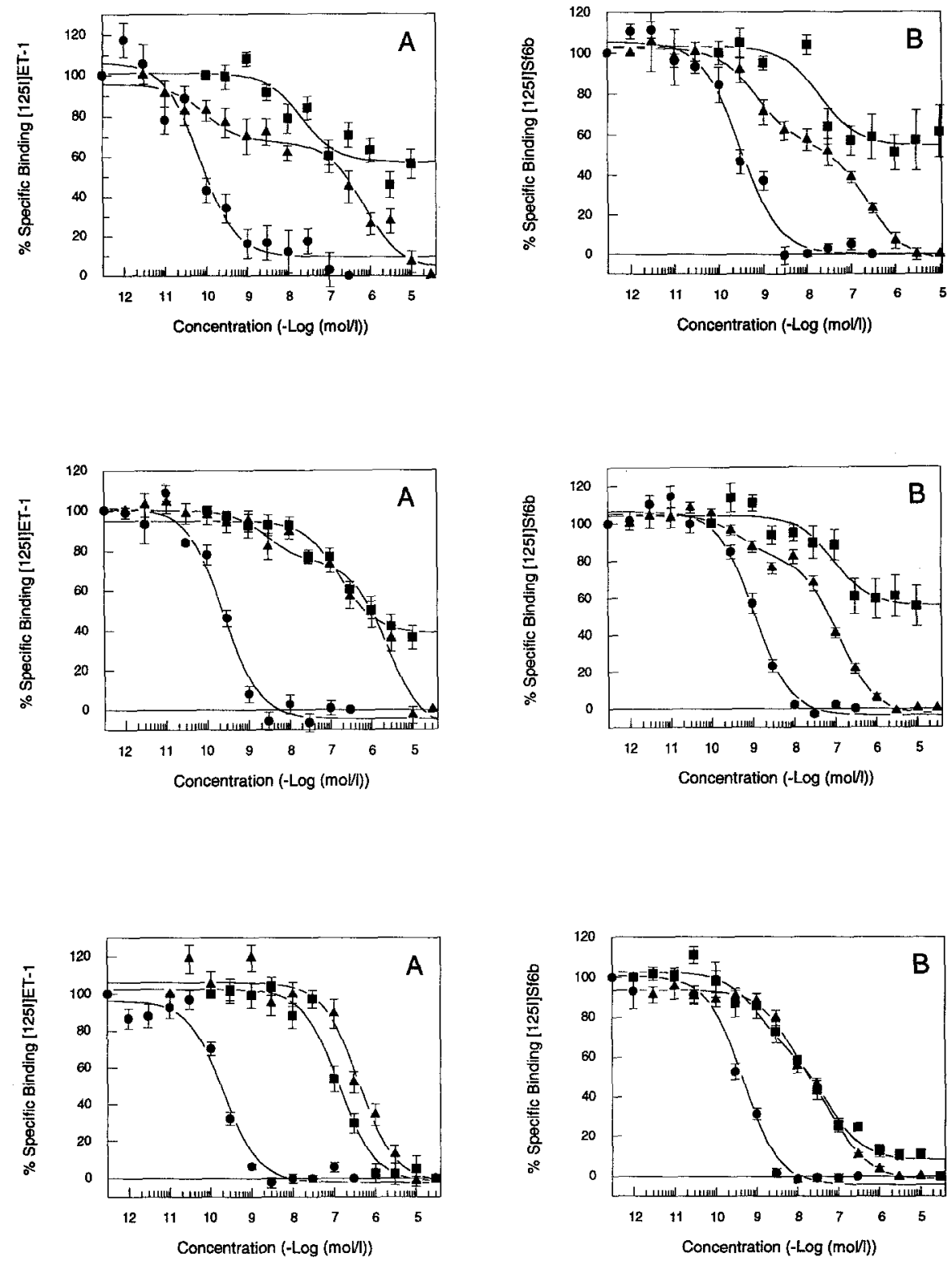

Fig. 3. Human left ventricle. Displacement ( $\%$ of total specific binding) of $\left[{ }^{125}\right.$ I]ET-1 (panel A) and $\left.{ }^{125} \mathrm{I}\right] \mathrm{Sf} 6 \mathrm{~b}$ (panel B) by ET-1 $(\bullet), B Q-123(\boldsymbol{\square})$ and $\left[\mathrm{Ala}^{1,3,11,15}\right] \mathrm{ET}-1$ (A)

Fig. 4. Human right atrium. Displacement ( $\%$ of total specific binding) of $\left[{ }^{125} \mathrm{I}\right] \mathrm{ET}-1$ (panel A) and $\left.{ }^{125} \mathrm{I}\right] \mathrm{Sf} 6 \mathrm{~b}$ (panel B) by ET-1 (•), BQ-123 (ש) and $\left[\mathrm{Ala}^{1,3,11,15}\right]$ ET-1 (A)
Fig. 5. Human coronary artery. Displacement ( $\%$ of total specific binding) of $\left[{ }^{125}\right.$ I]ET-1 (panel A) and $\left[{ }^{125}\right.$ I]Sf6b (panel B) by ET-1 $(\bullet), \mathrm{BQ}-123(\mathbf{\square})$ and $\left[\mathrm{Ala}^{1,3,11,15}\right] \mathrm{ET}-1(\boldsymbol{\Delta})$

Table 3. Human coronary artery. $\mathrm{pIC}_{50}\left(-\log \mathrm{IC}_{50}(\mathrm{~mol} / \mathrm{l})\right)$ for the monophasic displacement (pIC $\mathrm{C}_{50}$ mono) or, in case of biphasic displacement, the high (pIC $\mathrm{p}_{50}$ high) and low (pIC $\mathrm{PI}_{50}$ low) affinity value and proportion (\% high, $\%$ low) of the affinity phases of $\left[\mathrm{Ala}{ }^{1,3,11,15}\right]_{\mathrm{ET}}-1$ and $\mathrm{BQ}-123$. Slope factor of the curves (or pseudo Hill number), see De Lean et al. (1978)

\begin{tabular}{|c|c|c|c|c|c|}
\hline & & {$\left[{ }^{125} \mathrm{I}\right] \mathrm{ET}-1$} & Slope factor & {$\left[{ }^{125} 1\right] S f 6 b$} & Slope factor \\
\hline ET-1 & $\mathrm{pIC}_{50}$ & $9.72 \pm 0.02^{\mathrm{a}}$ & & $9.35 \pm 0.04$ & \\
\hline$\left[\mathrm{Ala}^{1,3,11,15}\right] \mathrm{ET}-1$ & $\begin{array}{l}\text { pIC }_{50} \text { mono } \\
\text { pIC } \\
\% 0 \text { high } \\
\% \text { high } \\
\text { pIC } 50 \text { low } \\
\% \text { low }\end{array}$ & $6.40 \pm 0.12^{\mathrm{a}}$ & $0.95 \pm 0.08$ & $\begin{array}{c}7.66 \pm 0.06^{\mathrm{b}} \\
8.40 \pm 0.14 \\
47.3 \pm 4.8 \\
6.99 \pm 0.09 \\
52.7 \pm 4.8\end{array}$ & $0.64 \pm 0.09$ \\
\hline
\end{tabular}

${ }^{a}$ Monophasic complete displacement

${ }^{\mathrm{b}} \mathrm{pIC}_{50}$ value when fitted to a monophasic model to calculate the slope factor of the curve 
for both the $\mathrm{ET}_{\mathrm{A}}$ and $\mathrm{ET}_{\mathrm{B}}$ receptor (Molenaar et al. 1993). These authors also found a (free wall) ventricular population of both $\mathrm{ET}_{\mathrm{A}}$ and $\mathrm{ET}_{\mathrm{B}}$ receptors in an approximate percentage of 60 and $40 \%$, respectively (present study 53 and $47 \%$, respectively). In our study the $\mathrm{pIC}_{50}$ values of ET-1, [Ala ${ }^{1,3,11,15}$ ]ET-1 and BQ-123 also fitted with a mixed $\mathrm{ET}_{\mathrm{A}} / \mathrm{ET}_{\mathrm{B}}$ receptor population. The high affinity of $\mathrm{BQ}-123\left(\mathrm{pK}_{\mathrm{D}} \approx 9\right)$, presumably for the $\mathrm{ET}_{\mathrm{A}}$ receptor, was however clearly higher in the study by Molenaar et al. (1993) than in our study $\left(\mathrm{pIC}_{50} \approx 7\right)$. Other $\mathrm{ET}_{\mathrm{A}}$ receptor assays, however, have reported $\mathrm{pIC}_{50}$ values for BQ-123 of approximately 7 (Nakamichi et al. 1992) or 8 (Ihara et al. 1991).

Also in the atrium we observed a mixed receptor population that appeared to consist of both $\mathrm{ET}_{\mathrm{A}}$ and $\mathrm{ET}_{\mathrm{B}}$ receptors. In the right atrium, the proportion of $\mathrm{ET}_{\mathrm{A}}$ receptors $\left(68 \% \mathrm{ET}_{\mathrm{A}}\right.$ vs. $32 \% \mathrm{ET}_{\mathrm{B}}$ receptors) was somewhat higher than in the ventricle. This was possibly due to a higher density of atrial $\mathrm{ET}_{\mathrm{A}}$ receptors and similar density of $\mathrm{ET}_{\mathrm{B}}$ receptors, since the overall ET receptor density was higher in the atrium. Endothelin has previously been shown to elicit positive inotropic responses in the human isolated atrium (Davenport et al. 1989; Brodde et al. 1992). However, ET-1 did not cause positive inotropic affects in six strips obtained from the human ventricle strip that responded normally to (-)-isoprenaline (Davenport et al. 1989) and caused only very small inotropic effects in another study (Moravec et al. 1989). In this respect, it is of interest that the receptor density in the ventricle of several animal species has previously been found to correspond to the effectiveness of ET-1 in producing a positive inotropic effect (Takanashi and Endoh 1991). Functionally differential effects on human atrial and ventricular tissue have also been observed for 5-hydroxytryptamine which produced a positive inotropic effect on the isolated atrium (Kaumann et al. 1991) which could not be shown in the ventricle (Jahnel et al. 1992; Schoemaker et al. 1992a, b). Therefore, one should be careful to extrapolate the clear positive inotropic response elicited by endothelin in the rabbit papillary muscle (Takanashi and Endoh 1991) and in the human atrium (Davenport et al. 1989; Brodde et al. 1992) to the human ventricle, until further functional experiments in the human ventricle have been performed.

\section{Endothelin receptors in the coronary artery}

Endothelin was originally described as a vasoconstrictor peptide (Yanagisawa et al. 1988). Since then, various reports have appeared on the nature of this contractile receptor. An $\mathrm{ET}_{\mathrm{A}}$ receptor appeared to be involved in the contractile response to ET-1 of the porcine coronary artery (Fukuroda et al. 1992), but a non-ET ${ }_{\mathrm{A}}$ receptor, different from the $\mathrm{ET}_{\mathrm{B}}$ receptor, seemed to be involved as well (Harrison et al. 1992). This contention was based on the finding that ET-3 recognized a sarafotoxin S6c (selective for the $\mathrm{ET}_{\mathrm{B}}$ receptor; Williams et al. 1991) sensitive receptor, which was not recognized by ET-1, thus ruling out the $\mathrm{ET}_{\mathrm{B}}$ receptor. ET-1 has also been shown to cause potent contractions of human coronary artery segments (Chester et al. 1989; Davenport et al. 1989; Hemsén et al.
1990), but until now the nature of the endothelin receptor in this particular tissue remains unknown.

The present results indicate that a receptor which shows similar affinities for ET-1, $\left[\mathrm{Ala}^{1,3,11,15}\right] \mathrm{ET}-1$ and BQ-123 as in the human ventricle and atrium is also present in the human coronary artery. Using in situ-hybridization to show the presence of mRNA for the receptor, Molenaar et al. (1993) provided further evidence that this endothelin receptor in the human ventricle and atrium is of the $\mathrm{ET}_{\mathrm{A}}$ subtype. Considering the biphasic and shallow displacement curves (Fig. 5), $\left.{ }^{125} \mathrm{I}\right] \mathrm{Sf} 6 \mathrm{~b}$ also appeared to label another binding site with high affinity for both $\left[\right.$ Ala $\left.^{1,3,11,15}\right]$ ET-1 and BQ-123 (Table 3). This binding site does not seem to be related to any of the thus far discovered endothelin receptors. Interestingly, unlabeled ET-1 completely displaces $\left[{ }^{125} \mathrm{I}\right] \mathrm{Sf} 6 \mathrm{~b}$ binding with high affinity, and thus also appears to have affinity for this 'unknown' binding site. On the other hand, iodinated ET-1 apparently does not bind to the 'unknown' binding site since ET-1, BQ-123 and [Ala $\left.{ }^{1,3,11,15}\right]$ ET-1 all cause monophasic displacement of $\left[{ }^{125} \mathrm{I}\right] \mathrm{ET}-1$. Whether indeed this $\left[{ }^{125} \mathrm{I}\right] \mathrm{Sf} 6 \mathrm{~b}-$ labeled binding site, showing high affinity for both BQ-123 and $\left[\mathrm{Ala}^{1,3,11,15}\right]$ ET-1, constitutes a new endothelin receptor in blood vessels, requires further investigation using other endothelin isopeptides like ET-3 and sarafotoxin S6c, in radioligand assays as well as in functional experiments. Also the existence of different affinity states for the same receptor, labeled by $\left[{ }^{125} \mathrm{I}\right] \mathrm{Sf} 6 \mathrm{~b}$, but not by $\left.{ }^{125} \mathrm{I}\right] \mathrm{ET}-1$, cannot be entirely excluded. This does however not apply to differences between high and low affinity phases for $\left[\mathrm{Ala}^{1,3,11,15}\right] \mathrm{ET}-1$ and $\mathrm{BQ}-123$ in the atrium and ventricle since the differences of $\mathrm{pIC}_{50}$ values appear too high for different affinity states of the same receptor (Tables 1,2). On the other hand, vascular receptor heterogeneity has previously been suggested by Sumner et al. (1992), who observed that ET-3-induced contractions of the rabbit thoracic aorta were antagonized by $\mathrm{BQ}-123$ with an estimated $\mathrm{pK}_{\mathrm{B}}$ value of 8.3 , whereas BQ-123 antagonized ET-1-induced contractile responses of the same tissue with a - presumably $\mathrm{ET}_{\mathrm{A}}$ receptor-related $-\mathrm{pA}_{2}$ of 6.9 .

\section{Endothelin receptors in the diseased heart}

When compared to healthy cardiac tissue (Bio Implant Services/Eurotransplant organ donor tissue), we observed no differences in atrial and ventricular endothelin receptor characteristics in diseased hearts (dilating cardiomyopathy, obtained from heart transplant recipients). However, it has to be kept in mind that the numbers of diseased hearts investigated $(n=2)$ is too small to note possible subtle differences. Other investigators also failed to show a difference between healthy and diseased tissue (Eisenmenger's syndrome, ischemic heart disease; Molenaar et al. 1993) in man. An experimentally induced congestive heart failure in dogs, however, was found to result in a downregulation of cardiac endothelin receptors, possibly due to an increased plasma endothelin level (Fan et al. 1992). An increased plasma endothelin level has also been noticed in a variety of human cardiovascular (and non-cardiovascular) diseases in man (Miller et al. 1993). 
In the human coronary artery obtained from cardiac transplantation patients for ischemic heart disease $(n=2)$, we have neither observed a higher density of receptors nor different receptor characteristics. However, it has to be remarked that the pathological changes in coronary artery diseased transplantation hearts are merely the end-stage of a disease, present in the vasculature of many subjects who are generally considered healthy.

In summary, we observed that both $\left[{ }^{125}\right.$ I]ET-1 and $\left[{ }^{125} \mathrm{I}\right] \mathrm{Sf} 6 \mathrm{~b}$ were found to label a population of $\mathrm{ET}_{\mathrm{A}}$ and $\mathrm{ET}_{\mathrm{B}}$ binding sites in the human ventricle and atrium. Using $\left[{ }^{125} \mathrm{I}\right] \mathrm{ET}-1$ we found a single receptor population in the human coronary artery with similar characteristics as the $\mathrm{ET}_{\mathrm{A}}$ receptor in the ventricle and atrium. However, the radioligand $\left[{ }^{125} \mathrm{I}\right] \mathrm{Sf} 6 \mathrm{~b}$ also labeled a binding site with characteristics different from the atrial and ventricular endothelin receptors. Further experiments are needed to demonstrate whether this binding site is indeed a new endothelin receptor in the human coronary artery.

Acknowledgements. The authors wish to thank the Rotterdam Heart Valve Bank (Thorax Centre, University Hospital Rotterdam, Dijkzigt/Bio Implant Services/Eurotransplant Foundation, Leiden, The Netherlands) for supplying the human heart tissue. W. A. B. is supported by the Netherlands Heart Foundation, grant no. 89.252 .

\section{References}

Arai H, Hori S, Aramori I, Ohkubo H, Nakanishi S (1990) Cloning and expression of a cDNA encoding an endothelin receptor. Nature 348:730-732

Bax WA, Bruinvels AT, Saxena PR, Hoyer D (1993) Endothelin receptors in human cardiac tissue; a quantitative autoradiographic analysis. Br J Pharmacol 108:112P (abstract)

Brodde O-E, Bais S, Broede A, Kunde K, Schäfer E, Zerkowski H-R (1992) Receptor systems mediating positive inotropic effect in isolated human right atrium. Br J Pharmacol 105:108P (abstract)

Chester AH, Dashwood MR, Clarke JG, Larkin SW, Davies GJ, Tadjkarimi S, Maseri A, Yacoub MH (1989) Influence of endothelin on human coronary arteries and localization of its binding sites. Am J Cardiol 63:1395-1398

Davenport AP, Nunez DJ, Hall JA, Kaumann AJ, Brown MJ (1989) Autoradiographical localization of binding sites for porcine ${ }^{125}$ I]Endothelin-1 in humans, pigs, and rats: functional relevance in humans. J Cardiovasc Pharmacol 13[suppl 5]:S166-S170

Davenport AP, Molenaar P, Kuc RE (1992) BQ123 and BQ2030 reveal endothelin $\mathrm{ET}_{\mathrm{A}}$ and $\mathrm{ET}_{\mathrm{B}}$ receptor sub-types in human cardiac ventricle and rat cerebellum. Br J Pharmacol 107:304P (abstract)

De Lean A, Munson PJ, Rodbard D (1978) Simultaneous analysis of families of sigmoidal curves: application to bioassay, radioligand assay, and physiological dose-response curves. Am J Physiol 235:E97-E102

De Nucci G, Thomas R, D'Orleans-Juste P, Antunes E, Walder C, Warner TD, Vane JR (1988) Pressor effects of circulating endothelin are limited by its removal in the pulmonary circulation and by the release of prostacyclin and endothelium-derived relaxing factor. Proc Natl Acad Sci USA 85:9797-9800

Fan T-HM, Himura Y, Hood WB, Liang C-S (1992) Endothelin receptors in the failing myocardium. Circulation 86[suppl I]:I $768(\mathrm{ab}-$ stract)

Fukuda N, Izumi Y, Soma M, Watanabe Y, Watanabe M, Hatano M, Sakuma I, Yasuda H (1990) L-N $\mathrm{N}^{\mathrm{G}}$-monomethyl arginine inhibits the vasodilating effects of low dose of endothelin-3 on rat mesenteric arteries. Biochem Biophys Res Commun 167:739-745

Fukuroda T, Nishikibe M, Ohta Y, Ihara M, Yano M, Ishikawa K, Fukami T, Ikemoto F (1992) Analysis of responses to endothelins in isolated porcine blood vessels by using a novel endothelin antagonist, BQ153. Life Sci, Lett 50:PL107-PL112

Harrison VJ, Randriantsoa A, Schoeffter P (1992) Heterogeneity of endothelin-sarafotoxin receptors mediating contraction of pig coronary artery. Br J Pharmacol 105:511-513

Hemsén A, Franco-Cereceda A, Matran R, Rudehill A, Lundberg JM (1990) Occurrence, specific binding sites and functional effect of endothelin in human cardiopulmonary tissue. Eur J Pharmacol 191:319-328

Ihara M, Noguchi K, Saeki T, Fukuroda T, Tsudicha S, Kimura S, Fukami T, Ishikawa K, Nishikibe M, Yano M (1991) Biological profiles of highly potent novel endothelin antagonists selective for the $\mathrm{ET}_{\mathrm{A}}$ receptor. Life Sci 50:247-255

Ishikawa T, Yanagisawa M, Kimura S, Goto K, Masaki T (1988a) Positive inotropic action of novel vasoconstrictor pepticle endothelin on guinea pig atria. Am J Physiol 255:H970-H973

Ishikawa T, Yanagisawa M, Kimura S, Goto K, Masaki T (1988b) Positive chronotropic effects of endothelin, a novel endothelium-derived vasoconstrictor peptide. Pflügers Arch 413:108-110

Jahnel U, Rupp J, Ertl R, Nawrath H (1992) Positive inotropic response to 5-HT in human atrial but not in ventricular heart muscle. Naunyn-Schmiedeberg's Arch Pharmacol 346:482-485

Kaumann AJ, Sanders L, Brown AM, Murray KJ, Brown MJ (1991) A

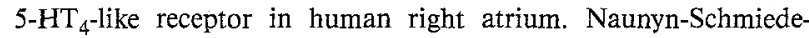
berg's Arch Pharmacol 344:150-159

Komuro I, Kurihara H, Sagiyama T, Takaku F, Yazaki Y (1988) Endothelin stimulates $\mathrm{c}$-fos and c-myc expression and proliferation of vascular smooth muscle cells. FEBS Lett 238:249-252

Kitayoshi T, Watanabe T, Shimamoto N (1989) Cardiovascular effects of endothelin in dogs: positive inotropic action in vivo. Eur J Pharmacol 166:519-522

Miller RC, Pelton JT, Huggins JP (1993) Endothelins - from receptors to medicine. Trends Pharmacol Sci 14:54-60

Molenaar P, Kuc RE, Davenport AP (1992) Characterization of two new $\mathrm{ET}_{\mathrm{B}}$ selective radioligands, $\left.{ }^{125} \mathrm{I}\right] \mathrm{BQ} 3020$ and $\left[{ }^{125} \mathrm{I}\right]$ [Ala ${ }^{1,3,11,15}$ ]ET-1 in human heart. Br J Pharmacol 107:637-639

Molenaar P, O'Reilly G, Sharkey A, Kuc RE, Harding DP, Plumpton C, Gresham GA, Davenport AP (1993) Characterization and localization of endothelin receptor subtypes in the human atrioventricular conducting system and myocardium. Circ Res 72:526-538

Moody CJ, Dashwood MR, Sykes RM, Chester M, Jones SM, Yacoub MH, Harding SE (1990) Functional and autoradiographic evidence for endothelin 1 receptors on human and rat cardiac myocytes; Comparison with single smooth muscle cells. Circ Res 67:764-769

Moravec CS, Reynolds EE, Stewart RW, Bond M (1989) Endothelin is a positive inotropic agent in human and rat heart in vitro. Biochem Biophys Res Commun 159:14-18

Nakamichi K, Ihara M, Kobayashi M, Saeki T, Ishikawa K, Yano M (1992) Different distribution of endothelin receptor subtypes in pulmonary tissues revealed by the novel selective ligands BQ-123 and $\left[\mathrm{Ala}^{1,3,11,15}\right.$ ET-1. Biochem Biophys Res Commun 182:144-150

Nambi P, Pullen M, Wu H-L, Aiyar N, Ohlstein EH, Edwards RM (1992) Identification of endothelin receptor subtypes in human renal cortex and medulla using subtype-selective ligands. Endocrinology 131:1081-1086

Ohlstein EH, Arleth A, Bryan H, Elliot JD, Sung CP (1992) The selective endothelin $\mathrm{ET}_{\mathrm{A}}$ receptor antagonist $\mathrm{BQ} 123$ antagonizes endothelin-1-mediated mitogenesis. Eur J Pharmacol 225:347-350.

Sakurai T, Yanagisawa M, Takuwa Y, Miyazaki H, Kimura S, Goto K, Masaki T (1990) Cloning of a cDNA encoding a non-isopeptide-selective subtype of the endothelin receptor. Nature 348:732-735

Saeki T, Ihara M, Fukuroda T, Yamagiwa M, Yano M (1991) $\left[{ }^{1,3,11,15}\right]$ Endothelin-1 analogs with $\mathrm{ET}_{\mathrm{B}}$ agonistic activity. Biochem Biophys Res Commun 179:286-292

Schoemaker RG, Du XY, Bax WA, Saxena PR (1992a) 5-Hydroxytryptamine increases contractile force in porcine right atrium but not in left ventricle. Naunyn-Schmiedeberg's Arch Pharmacol $346: 486-489$

Schoemaker RG, Du XY, Bax WA, Bos E, Saxena PR (1992b) 5-Hydroxytryptamine stimulates human isolated atrium but not ventricle. Eur J Pharmacol 230:103-105 
Shubeita HE, McDonough PM, Harris AN, Knowlton KU, Glembotski CC, Brown JH, Chien KR (1990) Endothelin induction of inositol phospholipid hydrolysis, sarcomere assembly, and cardiac gene expression in ventricular myocytes. J Biol Chem 265:20555-20562

Sumner MJ, Cannon TR, Mundin JW, White DG, Watts IS (1992) Endothelin $\mathrm{ET}_{\mathrm{A}}$ and $\mathrm{ET}_{\mathrm{B}}$ receptors mediate vascular smooth muscle contraction. Br J Pharmacol 107:858-860

Takanashi M, Endoh M (1991) Characterization of positive inotropic effect of endothelin on mammalian ventricular myocardium. Am J Physiol 261:H611-H619

Williams DL, Jones KL, Pettibone DJ, Lis EV, Clineschmidt BV (1991)
Sarafotoxin S6c: an agonist which distinguishes between endothelin receptor subtypes. Biochem Biophys Res Commun 175:556-561

Wright CE, Fozard JR (1988) Regional vasodilatation is a prominent feature of the haemodynamic response to endothelin in anaesthetized, spontaneously hypertensive rats. Eur $\mathrm{J}$ Pharmacol 155:201-203

Yanagisawa M, Kurihara H, Kimura S, Tomobe Y, Kobayashi M, Mitsui Y, Yazaki Y, Goto K, Masaki T (1988) A novel potent vasoconstrictor peptide produced by vascular endothelial cells. Nature 332:411-415 